\author{
A.A. Sumembayev ${ }^{*} 1,2$, A.N. Danilova ${ }^{1}$ \\ ${ }^{1}$ Altai Botanical Garden, Ridder, Kazakhstan; \\ ${ }^{2}$ Al-Farabi Kazakh National University, Almaty, Kazakhstan \\ *Corresponding author: aydars@list.ru
}

\title{
The comparative morphometric analysis of seeds representatives of the genus Paeonia L. (Paeoniaceae Rudolphi) of the Kazakh Altai's flora, introduced in the Altai Botanical Garden
}

\begin{abstract}
The article provides data on the study of the external structure, morphometric and weight parameters of seeds of the complex of Paeonia anomala L., P. hybrida Pall., P. intermedia C.A. Mey., grown in the conditions of the mountain-taiga zone of the Kazakhstan Altai, and clarification of the possibility of using these characters to distinguish between species. The primary analysis of the seed material revealed differences in the length, width and thickness of the seed in the cultivated samples from different ecological and geographical conditions of the habitats. A comparative study of such morphometric and weight parameters as the external structure, length, width, and thickness of seeds of the samples of Paeonia anomala, $P$. hybrida, P. intermedia, introduced from different ecological and geographical habitats of Kazakhstan Altai, revealed a certain variation in the selected parameters in the species. When comparing the external morphological structure of $P$. intermedia and $P$. anomala, the differences were practically not established, due to the close relationship of the species. When comparing the average metric and weight parameters of seeds in the Paeonia anomala specimens taken from ridge Ivanovsky, did not reveal significant differences. This happened despite the interpopulation difference in quality of the planting material with respect to ecology and location above sea level. This indicates the evenness of the length, width, and thickness of the seed material of the cultivated Paeonia anomala specimens. In cultivate specimens of $P$. hybrida from Narym ridge and Azutau in the ratio of the length, width and thickness of the seed, as well as the weight of 1000 pieces, seed differences were observed. Despite the low level of variability of morphological parameters of seeds, it is premature to recommend them for differentiation of species due to the short duration of the study period.
\end{abstract}

Keywords: Paeonia L., carpology, Kazakhstan Altai, introduction, category of rarity.

\section{Introduction}

The conservation of the Earth's biological diversity is one of the most important problems of modern biology. Its effective solution is possible only with a comprehensive study of the ecological-biological features of each species of plants. This is especially relevant for rare species, since research on their ecology and biology is not only of theoretical interest, but also necessary for the development of ways to protect these species [1]. The main reasons for the reduction of species of the genus Paeonia L. are anthropogenic effects on natural ecosystems and the collection of plants for medicinal and ornamental purposes [2].

Genus Paeonia L., includes 36 species [3], belongs to the number of systematically complex taxa of flowering plants [4]. Representatives of the genus are perennial herbs with thickened spindle-shaped roots and difficult palm-dissected leaves or tree-like shrubs (8 species) [5].

The fruit of the peony is apocarps leafy. A multi-leaflet is a collection of non-growing leaflets, each of which arises from a separate carpel. A separate leaflet can be called a fruit. The fruit is multi-seeded, opening suturally (along the abdominal suture). The pericarp is dry, the number of seeds is usually up to 10 or slightly more, but always less than the number of embedded seed bugs [6].

High morphological variability creates great difficulties in establishing boundaries between species [7]. There are controversial points in taxonomy and systematics of the genus [8]. Especially between P. anomala, $P$. intermedia and $P$. hybrida, forming a single complex of Siberian-Central Asian herbaceous species, characterized by twice tripartite strongly segmented leaves, covered with bristles on top of the veins. All species of complex are diploids [9]. Analysis of literary data on the state of study of the topic showed that information on the morphology of species of the genus Paeonia is clearly not enough to conduct a comparative morphometric analysis of seeds of the studied species [10-14].

The purpose of this work was to study the external structure, morphometric and weight indices of seeds Paeonia anomala L., Paeonia hybrida Pall., Paeonia intermedia C.A. Mey., grown under the conditions of culture, and find out the possibility of using these features to distinguish species. 


\section{Materials and Methods}

The object of the study was the seed material of three rare species of peonies: Paeonia anomala L., Paeonia hybrida Pall., Paeonia intermedia C.A. Mey, included to the introduction from various habitats of Kazakhstan Altai and grown in the exposition of the natural flora of the Altai Botanical Garden.

Paeonia anomala L. is boreal, mainly Siberian species, mesophyte. It distributes in the northern regions of European Russia, in Western Siberia, Baikal region, on Tien Shan, Mongolia. In Kazakhstan, it grows in the northern, eastern and southeastern regions: Caspian (Volga region), Kokchetau, Zaisan, Altai, Tarbagatai, Dzungar, Transili, Ketmen, Kyrgyz Alatau and on Western Tien Shan [5]. It prefers moistened meadows and fairly well-warmed and clarified forest glades. Throughout the range it occurs discretely, is intensively shrinking. It is included in the Red Book of Kazakhstan [15], in the regional Red Books of the Russian Federation [16-22].

Paeonia hybrida Pall. is the Central Asian mesoxerophyte species. The general distribution of the species is Western Siberia and Western China [23]. In Kazakhstan, it grows on the steppe slopes of foothills and shallow slopes, on steppe meadows, open rocky slopes of the lower mountain belt in geographical areas: Turkestan, Altai, Tarbagatai, Dzungar, Transili, Ketmen, Kyrgyz Alatau, Chu-Ili mountains (Krasnogorsk) and in Tien Shan. In 1991 it was found in the Republic of Bashkortostan [24]. It is included in the Red Book of Kazakhstan [15], the Red Book of Uzbekistan [25], the Red Book of the Altai Territory [26].

Paeonia intermedia C.A. Mey. is mesoxerophyte species, area covers Western Siberia, Chinese and Mongolian Altai [27]. In Kazakhstan, it is found in Kazakhstan Altai [28], Saur, Tarbagatai, Dzungar Alatau, Western Tien Shan [27]. The species is included in the Red Book of Tajikistan [29].

In climatic terms, the research area (Ridder, East Kazakhstan, geographical region: South-West Altai) is characterized by cold long winters, warm and humid summers, sharp temperature and humidity drops during the year, seasons of the day. According to the Ridder Weather Station, the area of introduction belongs to a moderately cool, moderately moistened agro-climatic zone. The climate is sharply continental, with an average annual air temperature of $+1.8^{\circ} \mathrm{C}$. The average monthly air temperature of the winter months ranges from $-5^{\circ} \mathrm{C}$ to $-16{ }^{\circ} \mathrm{C}$ with an absolute minimum of $-46,7{ }^{\circ} \mathrm{C}$, summer months from $+17{ }^{\circ} \mathrm{C}$ to $+25^{\circ} \mathrm{C}$ with an absolute maximum of $+41.5^{\circ} \mathrm{C}$. The average annual rainfall ranges from 432 to $937 \mathrm{~mm}$ with a summer maximum [30].

During describing the morphological features of seeds, special attention was paid to the size and structure of the surface of the seed, to a lesser extent to the shape and color. Well-made seeds were selected for analysis. The seeds were collected after the flyer flaps diverged when the seeds acquired a light brown or dark blue color [31]. Morphological characteristics of seeds were compiled using terminology presented in the works of Z.T. Artyushenko [32] and M.G. Nikolaeva et al. [31]. Morphometric measurements are made with a micrometer MK-25 in 20-25 times repetition for each parameter. The color palette of seeds is determined on the basis of the color scale of A.S. Bondartsev [33] and the color scale of the English Royal Society of Flower Growers [34]. The statistical analysis calculated the mean values of the analyzed indices (length, width, thickness of the seed with deviation from the mean and correlation coefficient) [35]. Latin plant names were verified according to S.K. Czerepanov [36]. The circuit map is made in QGIS 3.14.15 Pi.

\section{Results and Discussion}

As a result of the cameral treatment, the description of the external structure of the seeds Paeonia anomala L., Paeonia hybrida Pall., Paeonia intermedia C.A. Mey was carried out at 2019 samples of the collection site of the Altai Botanical Garden.

Paeonia anomala: seeds large, rounded, slightly flattened (Fig. 1, 2). Length: 6.15-7.25 (average 6.52) mm, width: 4.82-6.15 (average 5.47) $\mathrm{mm}$, thickness 2.99-5.04 (average 4.46) $\mathrm{mm}$. The mass of 1000 seeds is from 67 to $140 \mathrm{~g}$. The color is from brilliantly black to matte black, sometimes grayish in the lateral and chalazal parts. The color is mainly glossy. The shape of the seeds is spherical, sometimes slightly flattened in the back. The dough is rough, sometimes almost smooth; the surface is fine in places, always bare. The peel is dense, thick enough. In the abdominal part there are two unequal parallel recesses, oval in shape, forming a longitudinal protrusion between them. Often small circular depressions are found on the sides of the seed. Micropile is overgrown, invisible. The chalazal end narrows slightly to the base, usually smooth, rarely longitudinally wrinkled. Seed scar of medium size, linear type, longitudinally ellipsoidal in shape, sometimes almost oval, noticeably protruding; located in the basal part, less often in the lower part of the abdominal side. Rafe is absent. 

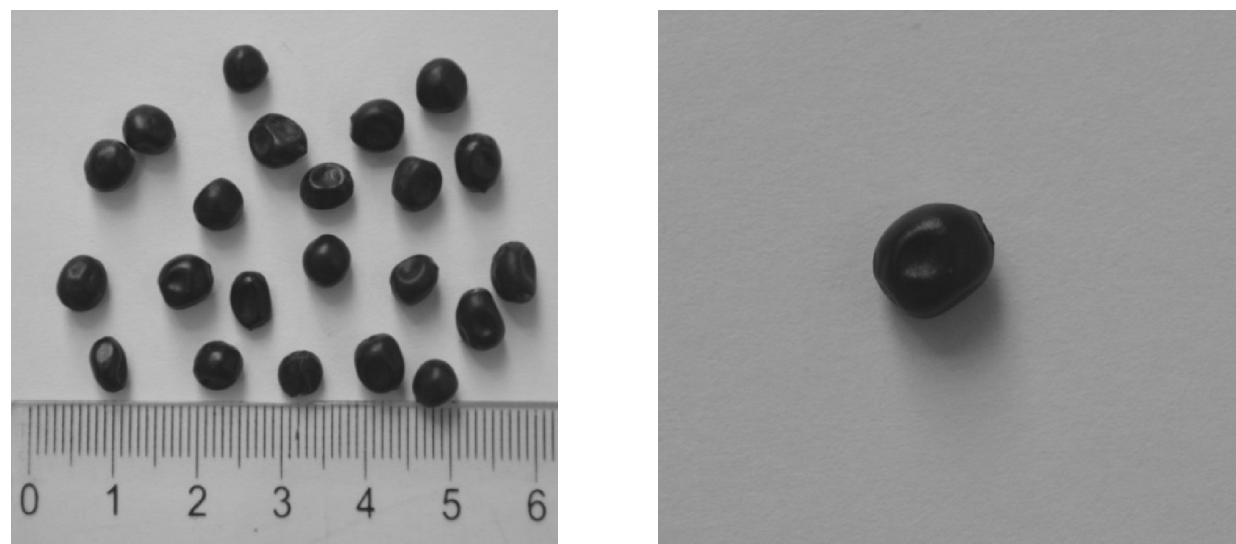

Figure 1 and 2. Seeds of Paeonia anomala L.

Paeonia hybrid: straight-type seeds, elongated (Fig. 3, 4). Length: 4.4-6.2 (average 5.41) mm, width: 3.1-3.8 (average 3.38) mm, thickness: 2.9-3.5 (average 3.18) $\mathrm{mm}$. The mass of 1000 pieces of seeds is from 28 to $37 \mathrm{~g}$. The color of the seeds is from brown-brown to dark brown. Seeds have a characteristic gloss. The seed peel is smooth, rarely with small roughness, sometimes finely chopped. The surface of the seeds is bare, without pubescence. The dough is very dense, strong. Often, the surface of the seeds can be longitudinally rigid in the abdominal and lateral parts, with characteristic clearly pronounced cellular gyros. The shape of the seeds is barrel-shaped, ellipsoidal in shape, noticeably thickened in the middle part. The micropile is overgrown, clearly pronounced formed by external integrations, longitudinally slit-shaped, elongated into a small well-distinguished spout. The halazal end is noticeably narrowed, passing into a seed scar. The medium-sized seed scar is longitudinally slit-shaped, basal, protruding. Rafe is clearly pronounced, narrow, and clearly distinguishable to micropiles.
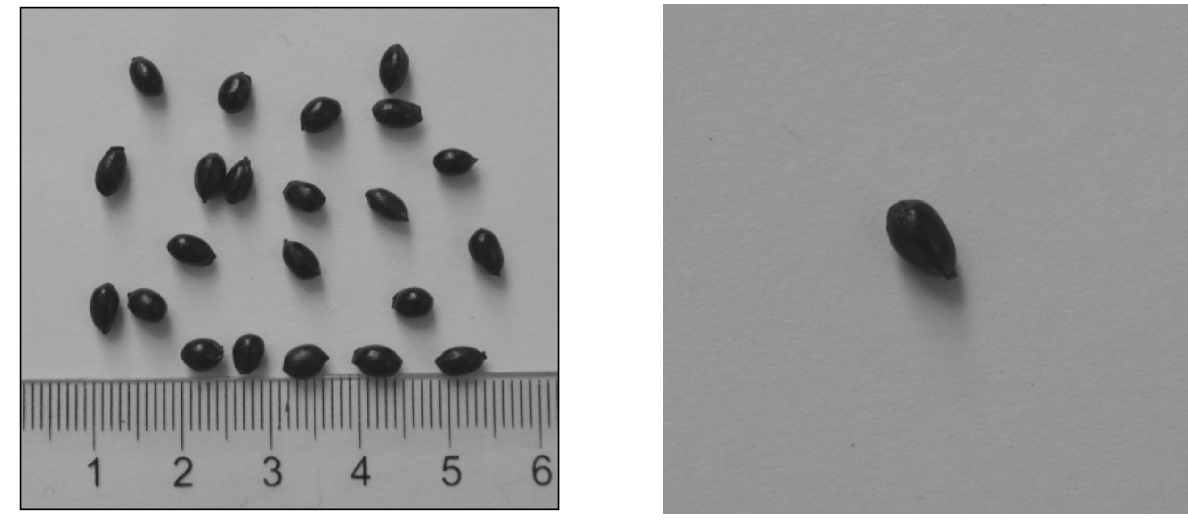

Figure 3 and 4. Seeds of Paeonia hybrida

Paeonia intermedia: seeds are large, rounded; length: 6.78-8.33 (average 7.17) mm, width 4.93-6.52 (average 5.41) mm, thickness 4.41-5.26 (average 4.82) $\mathrm{mm}$; The mass of 1000 pieces of seeds is $96.74 \mathrm{~g}$. The color gamut of the seeds varies from gray-slate to coal-black. The color is mainly matte, sometimes glossy. Slightly lighter in the thickened part, ovate or oblong-ovate in shape, noticeably volumetric and convex in the back. The seed peel is quite dense, strong and thick. The surface of the seeds is almost smooth, sometimes slightly rough, finely grained, glabrous; without any pubescence. In the abdominal part of the seed there is a significant notch, less often two, oval or oblong-ellipsoidal in shape. In the dorsal part of the seed there are sometimes weakly expressed intrusions. The microplar entrance is completely overgrown, located in a characteristic small rounded decrease; located in a smoothly tapering end of the seed. The halazal end is aligned, usually has a smooth surface, sometimes slightly thickened, sharply tapering to the seed scar. Seed scar of rather large size, basal, linear type, quadrangular shape, short, slightly protruding, longitudinal location. There is always no rafe (Fig. 5, 6). 

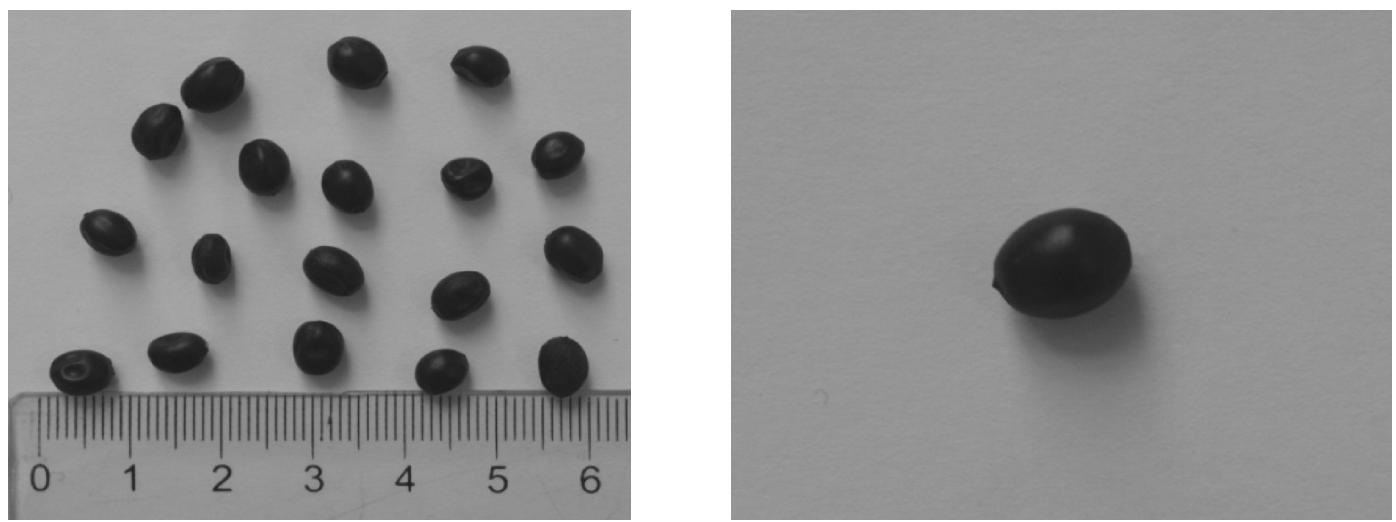

Figure 5 and 6. Seeds of Paeonia intermedia C.A. Mey

It is noted that $P$. intermedia and $P$. anomala seeds are almost identical in external structure. This is probably directly related to the close relationship of these species, which were previously assigned to one species. For comparative analysis of morphometric and weight indices we carried out statistical processing of seeds (collection 2016) of studied species Paeonia anomala and Paeonia hybrida, attracted to introduction in different periods from different ecological and geographical habitats of Kazakhstan Altai (Fig. 7).

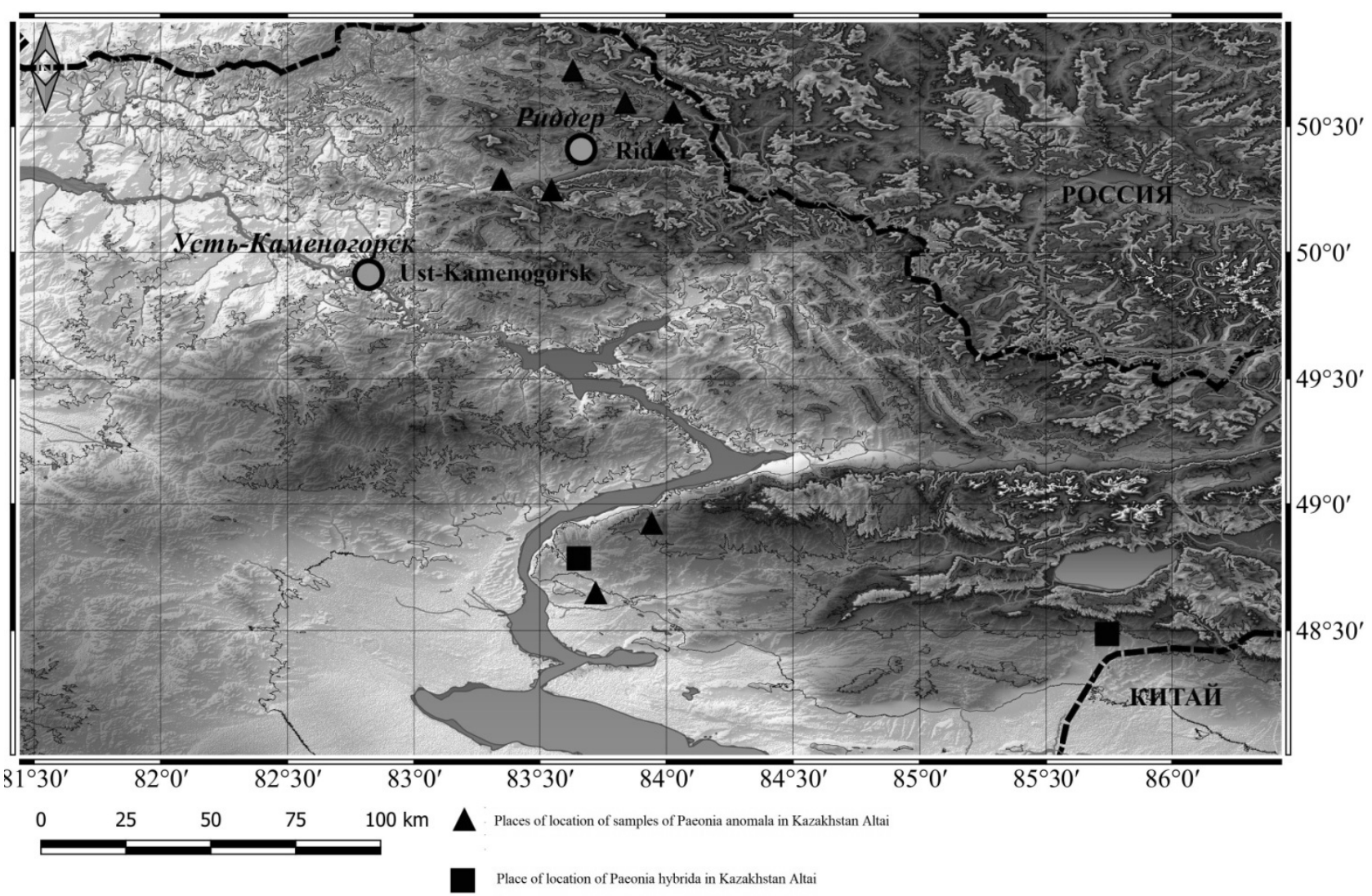

Figure 7. Scheme - map of ecological and geographical habitats of different samples of species Paeonia anomala and Paeonia hybrida in the territory of Kazakhstan Altai

Data for the comparative analysis is presented in Table 1. 
$\mathrm{Table} 1$

\section{Biometric indicators of seeds of Paeonia anomala and Paeonia hybrida in introduction from different ecological-geographical habitats of Kazakhstan Altai}

\begin{tabular}{|c|c|c|c|c|c|c|c|}
\hline \multirow[b]{2}{*}{ Sample origin } & \multicolumn{2}{|c|}{ Seed length, mm } & \multicolumn{2}{|c|}{ Seed width, mm } & \multicolumn{2}{|c|}{ Seed thickness, mm } & \multirow{2}{*}{$\begin{array}{c}\text { Mass of } \\
1000 \text { seeds, } \\
\mathrm{g}\end{array}$} \\
\hline & $\stackrel{\mathrm{M} \pm \mathrm{m}}{\mathrm{Min}-\mathrm{Max}}$ & $\mathrm{Cv}, \%$ & $\frac{\mathrm{M} \pm \mathrm{m}}{\mathrm{Min}-\mathrm{Max}}$ & $\mathrm{Cv}, \%$ & $\underline{\mathrm{M} \pm \mathrm{m}}$ & $\mathrm{Cv}, \%$ & \\
\hline \multicolumn{8}{|c|}{ Paeonia anomala } \\
\hline $\begin{array}{l}\text { Ivanovsky ridge, tract Broad Log, } \\
1400 \mathrm{~m} \text { above sea level }\end{array}$ & $\frac{6.52 \pm 0.16}{6.15-7.25}$ & 4.43 & $\frac{5.47 \pm 0.19}{4.82-6.15}$ & 7.02 & $\frac{4.46 \pm 0.28}{2.99 \pm 5.04}$ & 11.53 & 85.26 \\
\hline $\begin{array}{l}\text { Ridge Ivanovsky, the upper reaches } \\
\text { of the Kazachikha River, eastern } \\
\text { slope, sparse cedar, } 1900 \mathrm{~m} \text { above } \\
\text { sea level }\end{array}$ & $\frac{6.64 \pm 0.26}{5.84-7.7}$ & 7.15 & $\frac{4.97 \pm 0.19}{4.5-5.7}$ & 7.12 & $\frac{3.79 \pm 0.21}{3.24-4.3}$ & 10.1 & 73.61 \\
\hline $\begin{array}{l}\text { Ridge Ivanovsky, gorge «Gray } \\
\text { Meadow», north-western slope, co- } \\
\text { niferous forest, } 1200 \mathrm{~m} \text { above sea } \\
\text { level }\end{array}$ & $\frac{6.54 \pm 0.25}{5.8-7.1}$ & 6.94 & $\frac{5.41 \pm 0.23}{4.7-6.1}$ & 8.17 & $\frac{4.52 \pm 0.28}{3.6-5.2}$ & 11.1 & 82.18 \\
\hline $\begin{array}{l}\text { Ridge Ivanovsky, «Passage» belok, } \\
\text { north-western slope, } 1600 \mathrm{~m} \text { above } \\
\text { sea level }\end{array}$ & $\frac{6.61 \pm 0.21}{5.7-7.3}$ & 6.02 & $\frac{5.03 \pm 0.2}{4.5-5.8}$ & 7.6 & $\frac{4.15 \pm 0.29}{3.1-5.1}$ & 12.8 & 74.29 \\
\hline $\begin{array}{l}\text { Ridge Ivanovsky, northern spur, } \\
\text { tract «Haircut Pit,» } 1100 \text { m above } \\
\text { sea level, fir forest with an admix- } \\
\text { ture of birch }\end{array}$ & $\frac{6.79 \pm 0.17}{6.3-7.3}$ & 4.5 & $\frac{5.06 \pm 0.19}{4.3-5.6}$ & 7.16 & $\frac{4.04 \pm 0.33}{2.9-5.0}$ & 15.1 & 77.77 \\
\hline $\begin{array}{l}\text { Ridge Ubinsky, southeastern spurs, } \\
\text { Kozlushka Mount, surrounding } \\
\text { Butakovo, } 710 \mathrm{~m} \text { above sea level }\end{array}$ & $\frac{6.72 \pm 0.3}{6.19-7.87}$ & 8.12 & $\frac{4.92 \pm 0.29}{4.19-5.75}$ & 11.1 & $\frac{3.87 \pm 0.29}{2.61-5.01}$ & 13.9 & 67.99 \\
\hline $\begin{array}{l}\text { Ridge Kurchumsky, northern slope, } \\
\text { surrounding Kurchum, } 503 \text { m above } \\
\text { sea level }\end{array}$ & $\frac{7.83 \pm 0.22}{7.1-8.4}$ & 5.14 & $\frac{6.21 \pm 0.13}{5.7-6.5}$ & 3.92 & $\frac{5.75 \pm 0.21}{5.3-6.6}$ & 6.5 & 139.59 \\
\hline $\begin{array}{l}\text { Ridge Narymsky, gorge Akbulak, } \\
\text { north-western crushed slope, } 940 \mathrm{~m} \\
\text { above sea level }\end{array}$ & $\frac{7.23 \pm 0.25}{5.8-7.7}$ & 6.39 & $\frac{5.11 \pm 0.22}{4.5-5.6}$ & 7.71 & $\frac{4.27 \pm 0.19}{3.6-5.1}$ & 9.13 & 86.55 \\
\hline \multicolumn{8}{|c|}{ P. hybrida } \\
\hline $\begin{array}{l}\text { Narymsky ridge, Tolebay tract, } \\
\text { north-western crushed slope, } 740 \mathrm{~m} \\
\text { above sea level }\end{array}$ & $\frac{5.41 \pm 0.24}{4.4-6.2}$ & 8.02 & $\frac{3.38 \pm 0.12}{3.1-3.8}$ & 6.72 & $\frac{3.18 \pm 0.09}{2.9 \pm 3.5}$ & 5.67 & 28.22 \\
\hline $\begin{array}{l}\text { Ridge Azutau, Koytas tract, south- } \\
\text { western slope, } 777 \mathrm{~m} \text { above sea lev- } \\
\text { el }\end{array}$ & $\frac{5.55 \pm 0.21}{5.1-5.9}$ & 5.25 & $\frac{3.51 \pm 0.13}{3.2-3.7}$ & 5.02 & $\frac{3.3 \pm 0.11}{3.1-3.6}$ & 4.67 & 36.11 \\
\hline
\end{tabular}

Note. in numerator: $\mathrm{M} \pm \mathrm{m}$ — average value \pm permissible limits; in denominator: Min-Max — minimum and maximum value.

Primary analysis of Paeonia anomala seeds revealed differences in the length, width and thickness of the seed in cultivated samples from different ecological-geographical habitats. The largest seeds are collected from a sample imported from range Kurchumsky, $503 \mathrm{~m}$ above sea level, in which the mass of 1000 seeds is $139.59 \mathrm{~g}$, dimensions: length $-7.83 \pm 0.22 \mathrm{~mm}$, width $-6.21 \pm 0.13 \mathrm{~mm}$. Large seeds produce individuals originating from range Narymsky (gorge Akbulak, $940 \mathrm{~m}$ above sea level), in which the mass of 1000 seeds is $86.55 \mathrm{~g}$, dimensions: length $-7.23 \pm 0.25 \mathrm{~mm}$, width $-5.11 \pm 0.22 \mathrm{~mm}$. Seed material from samples from the Ubinsky ridge (Kozlushka Mount, $710 \mathrm{~m}$ above sea level) has the smallest mass of 1000 seeds $-67.99 \mathrm{~g}$ and intermediate parameters of the length and width of the seeds compared to Paeonia anomala samples collected from range Ivanovsky, Narymsky and Kurchumsky.

Study in culture of average biometric and weight indices of seeds in Paeonia anomala samples collected with range Ivanovsky did not reveal significant differences, despite the inter-population diversity of the planting material relative to ecology and location above sea level.

The coefficients of variation in the length, width and thickness of the seed showed that the studied features have similar variation amplitudes in all samples and correspond to a low level of variability. This indi- 
cates that the length, width and thickness of the seed material of the cultivated Paeonia anomala samples are aligned.

Similar results during the statistical processing of morphometric and weight indices were found for P. hybrida seeds. In cultivated samples of the species with range Narymsky and Azutau showed slight differences in the ratio of the length, width and thickness of the seed, as well as the mass of 1000 seeds. It was also found that for both species, the coefficients of variation of these indicators have a low degree of variability.

\section{Conclusion}

A comparative study of such morphometric and weight parameters as external structure, length, width, seed thickness of samples Paeonia anomala, P. hybrida, P. intermedia, collected from different ecological and geographical habitats of Kazakhstan Altai, revealed a certain variation of selected indicators in species. Apparently, this is related to the origin of material from geographically distant populations. However, when comparing the external structure of $P$. intermedia and $P$. anomala seeds, differences are practically not established. There is probably a close relationship between these species, previously attributed to the same species $P$. anomala. After comparing average metric and weight values of seeds in Paeonia anomala samples attracted from range Ivanovsky did not reveal significant differences, despite the inter-population diversity of the planting material relative to ecology and location above sea level.

Despite the low level of variability of morphological indicators of seeds, it is premature to recommend them for differentiation of species due to the short-term period of research.

\section{Acknowledgements}

The article was prepared with the financial support of the Scientific and Technical Programme «Development of scientific and practical foundations and innovative approaches for the introduction of plants in the natural zones of Western and Eastern Kazakhstan for rational and effective use in landscaping, gardening and environmental protection» of the Ministry of Education and Science of the Republic of Kazakhstan (2021-2022).

\section{References}

1 Миногина Е.Н. Семенная продуктивность видов Helianthemum nummularium и H. baschkirorum в ценопопуляциях на Урале / Е.Н. Миногина // Перспективы развития и проблемы современной ботаники: Материалы I (III) Всерос. молод. науч.практ. конф. ботаников. - Новосибирск, 2007. - С. 223, 224.

2 Рудая О.А. Причины покоя семян некоторых видов рода Раеопіа L. / О.А. Рудая, О.В. Чернышенко, С.В. Ефимов, Г.Н. Кононов // Лесн. вестн. - 2016. - № 2. - С. 66-73.

3 The Plant List (2013). Version 1.1. [online resource]. URL: http://www.theplantlist.org/

4 Успенская М.С. Дополнения к системе рода Раеопіа L. / М.С. Успенская // Бюл. МОИП. — 1987. — Т. 92, Вып. 3. C. $79-85$.

5 Флора Казахстана. - Алма-Ата, 1961. - Т. 4. - 545 с.

6 Реут А.А. Семенная продуктивность дикорастущих пионов и способы её повышения / А.А. Реут // Научные ведомости Белгор. гос. ун-та. Сер. естест. науки. — 2011. — № 3 (98), Вып. 14/1. — С. 134-139.

7 Ефимов С.В. Взаимоотношение видов Paeonia anómala, P intermedia и P. hybrida (Paeoniaceae) по данным о последовательностях ITS ядерной рибосомной ДНК и усfl хлоропластной ДНК / С.В. Ефимов // Проблемы ботаники Южной Сибири и Монголии. — 2016. - № 15. — С. 112-116.

8 Pan J. Molecular phylogenetic evidence for the origin of a diploid hybrid of Paeonia (Paeoniaceae) / J. Pan, D. Zhang, T. Sang // American Journal of Botany. — 2007. - T. 94, № 3. - C. 400-408.

9 Wang S.Q. Karyotype in Paeonia intermedia C.A. Mey / S.Q. Wang // Bangladesh J. Bot. — 2014. — Vol. 43. - P. 101105.

10 Черней Е.Н. Строение околоплодника и семени пиона иноземного / Е.Н. Черней // Изв. АН МССР. Сер. биол. и хим. наук. - 1985. — № 5. - С. 58-60.

11 Сравнительная анатомия семян. - Л.: Наука, 1988. - Т. 2. - 255 с.

12 Беляева T.Н. Морфология семян видов Paеопia L. / Т.Н. Беляева // Систематические заметки по материалам гербария им. П.Н. Крылова Том. гос. ун-та. - 2000. - С. 25-27.

13 Реут А.А. Карпология некоторых видов рода Paeonia L. (Paеoniaceae), интродуцированных в Башкирском Предуралье / А.А. Реут, Л.Н. Миронова // Карпология и репродуктивная биология высших растений: материалы Всерос. науч. конф. с междунар. участием, посвящ. памяти проф. А.П. Меликяна. - М., 2011. — С. 310-312.

14 Zhang K. A review of the seed biology of Paeonia species (Paeoniaceae), with particular reference to dormancy and germination / K. Zhang, L. Yao, Y. Zhang, J.M. Baskin, C.C. Baskin, Z. Xiong, J. Tao // Planta. - 2018. — Vol. 249, Iss. 2. — P. 291$303 \mathrm{https} / / /$ doi.org/10.1007/s00425-018-3017-4

15 Красная книга Казахстана. - Т. 2: Растения. - Астана, 2014. — 452 с. 
16 Красная книга Ямало-Ненецкого автономного округа: животные, растения, грибы. — Екатеринбург: Изд-во Урал. ун-та, 1997. - $240 \mathrm{c}$.

17 Красная книга Курганской области. - Курган: Зауралье, 2002. — 424 с.

18 Красная книга Ханты-Мансийского автономного округа: животные, растения, грибы. — Екатеринбург: Пакрус, 2003. $-376 \mathrm{c}$.

19 Красная книга Тюменской области. — Екатеринбург: Изд-во Урал. ун-та, 2004. — 496 с.

20 Красная книга Омской области. — Омск: Изд-во ОмГПУ, 2005. - 460 с.

21 Красная книга Республики Башкортостан: редкие и исчезающие виды высших сосудистых растений. — Уфа: Китап, 2001. - T. 1. - $280 \mathrm{c}$.

22 Красная книга Республики Коми. - Сыктывкар: Коми НЦ УрО РАН, 2009. — 791 с.

23 Флора Сибири. - Новосибирск: Наука, 1993. — Т. 6. - 310 с.

24 Мулдашев А.А. Флористические находки в Башкортостане (Россия) / А.А. Мулдашев // Бот. журн. - 2003. - Т. 88, № 1. - C. 120-129.

25 Красная книга Республики Узбекистан: редкие и исчезающие виды растений и животных. - Tашкент: Chinor ENK, 2009. - Т. 1: Растения и грибы. - 356 с.

26 Красная книга Алтайского края. Редкие и находящиеся под угрозой исчезновения виды растений. — Барнаул: ОАО «Алтай», 2006. — 262 с.

27 Камелин Р.В. Материалы по истории флоры Азии (Алтайская горная страна) / Р.В. Камелин. — Барнаул: Изд-во Алтай. гос. ун-та, 1998. - $236 \mathrm{c}$.

28 Котухов Ю.А. Список сосудистых растений Казахстанского Алтая / Ю.А. Котухов // Ботанические исследования Сибири и Казахстана. - 2005. - Вып. 11. - С. 11-83.

29 Красная книга Таджикистана. - Душанбе, 2015. - 535 с.

30 Алтайскому ботаническому саду — 80 лет: альманах. — Усть-Каменогорск: Медиа-Альянс, 2015. — 58 с.

31 Николаева М.Г. Биология семян / М.Г. Николаева, И.В. Лянгузова, Л.М. Поздова. - СПб., 1999. — 234 с.

32 Артюшенко 3.Т. Атлас по описательной морфологии высших растений: Семя / 3.Т. Артюшенко. - Л., 1990. — 204 с.

33 Бондарцев А.С. Шкала цветов / А.С. Бондарцов. - М., 1954. - 28 с.

34 Цветовая шкала Английского Королевского общества цветоводов (RHS ColourChart). [Электронный pecypc]. URL: http://traditio-ru.org/wiki/ (RHS_Colour_Chart).

35 Зайцев Г.Н. Математика в экспериментальной ботанике / Г.Н. Зайцев. - М., 1990. — 296 с.

36 Черепанов С.К. Сосудистые растения России и сопредельных государств (в пределах бывшего СССР) / С.К. Черепанов. - СПб., 1995. - 990 с.

\title{
А.А. Сумембаев, А.Н. Данилова
}

\section{Алтай Ботаникалық бағына жерсіндірілген Қазақстан Алтайының флорасының Paeonia L. (Paeoniaceae Rudolphi) туыстасының өкілдерінің тұқымдарының морфометриялық салыстырмасы}

\begin{abstract}
Мақалада Paeonia anomala L., P. hybrida Pall., P. intermedia C.A. Меу түрлер тұқымдарының сыртқы құрылымын, морфометриялық және салмақтық параметрлерін кешенді зерттеу туралы мәліметтер келтірілген. Және де Қазақстан Алтайының таулы-тайга зонасы жағдайында өсірілген және түрлерді ажырату үшін осы таңбаларды қолдану мүмкіндігін нақтылау сипатталған. Тұқым материалының алғашқы талдауында әр түрлі экологиялық-географиялық жағдайлардан алынған өсінді үлгілеріндегі тұқымның ұзындығы, ені мен қалыңдығындағы айырмашылықтар анықталды. Paeonia anomala, P.hybrida, P. intermedia үлгілерінің тұқымдарының сыртқы құрылымы, ұзындығы, ені және қалыңдығы сияқты тұқымдардың морфометриялық және салмақтық параметрлерін салыстырмалы түрде зерттеу барысында Алтайдың әр түрлі экологиялық-географиялық тіршілік ету орталарынан енгізілгені бола тұрып, таңдалған түрдегі параметрлердің белгілі бір ауытқуын анықтады. P. intermedia мен P. anomala-ның сыртқы морфологиялық құрылымын салыстыру кезінде бұл түрлердің тығыз байланысына байланысты айырмашылықтар іс жүзінде анықталмады. Тұқымдардың орташа метрикалық және салмақтық параметрлерін Ивановский жотасынан алынған P. anomala үлгілерімен салыстыру кезінде, экологияға және отырғызу материалының сапасының популяциялар арасындағы әртүрлілігіне және теңіз деңгейінен жоғары орналасуына қарамастан айтарлықтай айырмашылықтарды анықтаған жоқ. Бұл өсірілген P. anomala үлгілерінің тұқым материалының ұзындығының, енінің және қалыңдығының біркелкілігін көрсетеді. Нарын мен Азутау жоталарынан алынған P. hybrida түрлерінің өсірілген үлгілерінде тұқымның ұзындығына, еніне және қалыңдығына, сондай-ақ 1000 дана салмағына тұқымдық айырмашылықтар байқалды. Тұқымдардың морфологиялық параметрлерінің өзгергіштік деңгейінің төмендігіне қарамастан, оларды зерттеу кезеңінің қысқа болуына байланысты түрлерді саралауға ұсыну ерте.
\end{abstract}

Кілт сөздер: Paeonia L., карпология, Қазақстандағы Алтай, жерсіндіру, сирек категориясы. 
А.А. Сумембаев, А.Н. Данилова

\title{
Сравнительная морфометрия семян представителей рода Paeonia L. (Paeoniaceae Rudolphi) флоры Казахстанского Алтая, интродуцированных в Алтайском ботаническом саду
}

\begin{abstract}
В статье приведены данные по изучению внешнего строения, морфометрических и весовых показателей семян комплекса видов Paeonia anomala L., P. hybrida Pall., P. intermedia C.A. Mеу., выращиваемых в условиях горно-таежной зоны Казахстанского Алтая, и выявлены возможности использования данных признаков для разграничения видов. Первичный анализ семенного материала показал отличия по длине, ширине и толщине семени у культивируемых образцов из разных эколого-географических условий местообитаний. Сравнительное изучение таких морфометрических и весовых параметров, как внешнее строение, длина, ширина, толщина семян образцов Paeonia anomala, P. hybrida, P. intermedia, интродуцированных из разных эколого-географических местообитаний Казахстанского Алтая, выявило определенное варьирование выбранных показателей у видов. При сравнении внешнего морфологического строения семян $P$. intermedia и $P$. anomala различия практически не установлены ввиду близкого родства видов. Сравнение средних метрических и весовых показателей семян у образцов Раеопia anomala, привлеченных с хр. Ивановский, не дало значительных различий, несмотря на межпопуляционную разнокачественность посадочного материала относительно экологии и расположения над уровнем моря, что свидетельствует о выровненности показателей длины, ширины и толщины семенного материала культивируемых образцов Paeonia anomala. У культивируемых образцов $P$. hybrida вида с хр. Нарымский и Азутау в соотношении показателей длины, ширины и толщины семени, а также массы 1000 шт. семян наблюдались незначительные различия. Несмотря на низкий уровень изменчивости морфологических показателей семян, рекомендовать их для разграничения видов преждевременно из-за краткосрочности периода исследований.
\end{abstract}

Ключевые слова: Paeonia L., карпология, Казахстанский Алтай, интродукция, категория редкости.

\section{References}

1 Minogina, E.N. (2007). Semennaia produktivnost vidov Helianthemum nummularium i H. baschkirorum $\mathrm{v}$ tsenopopuliatsiiakh na Urale [Seed productivity of Helianthemum nummularium and H. baschkirorum species in cenopopulations in the Urals]. Proceedings from Prospects of development and problems of modern botany: I (III) Vserossiiskaia molodezhnaia nauchno-prakticheskaia konferentsiia botanikov - (III) All-Russian Youth Sci.-Pract. Conf. of botanists. (p. 223, 224). Novosibirsk [in Russian].

2 Rudaya, O.A., Chernyshenko, O.V., Efimov, S.V., \& Kononov, G.N. (2016). Prichiny pokoia semian nekotorykh vidov roda Paeonia L. [Causes of dormancy of seeds of some species of the genus Paeonia L.]. Lesnoi vestnik - Forest Bullein, 2, 66-73 [in Russian].

3 The Plant List (2013). Version 1.1. www.theplantlist.org Retrieved from http://www.theplantlist.org/.

4 Uspenskaia, M.S. (1987). Dopolneniia k sisteme roda Paeonia L. [Additions to the system of the genus Paeonia L.]. Biulleten MOIP - Bulletin of MSIN, 92 (3), 79-85 [in Russian].

5 Flora Kazakhstana [Flora of Kazakhstan]. (1961). (Vol. 4). Alma-Ata [in Russian].

6 Reut, A.A. (2011). Semennaia produktivnost dikorastushchikh pionov i sposoby ee povysheniia [Seed productivity of wild peonies and ways to increase it]. Nauchnye vedomosti Belhorodskoho hosudarstvennoho universiteta. Seriia estestvennye nauki Scientific Bulletin of Belgorod State University. Series natural science, 3 (98), 14/1, 13-139 [in Russian].

7 Efimov, S.V. (2016). Vzaimootnoshenie vidov Paeonia anómala, $P$ intermedia i P. hybrida (Paeoniaceae) po dannym o posledovatelnostiakh ITS yadernoi ribosomnoi DNK i ycfl hloroplastnoi DNK [The relationship between the species Paeonia anómala, $P$ intermedia, and $P$. hybrida (Paeoniaceae) according to the ITS sequences of nuclear ribosomal DNA and ycfl chloroplast DNA]. Problemy botaniki Yuzhnoi Sibiri i Monholii - The problems of botany of Southern Suberia and Mongolia, 15, $112-116$ [in Russian].

8 Pan, J., Zhang, D., \& Sang, T. (2007). Molecular phylogenetic evidence for the origin of a diploid hybrid of Paeonia (Paeoniaceae). American Journal of Botany, 94 (3), 400-408.

9 Wang, S.Q. (2014). Karyotype in Paeonia intermedia C.A. Mey. Bangladesh J. Bot., 43, 101-105.

10 Chernei, E.N. (1985). Stroenie okoloplodnika i semeni piona inozemnoho [The structure of the pericarp and the seed of a foreign peony]. Izvestiia AN MSSR. Seriia biolohicheskikh i khimicheskikh nauk - Bulletin of the Academy of Science MSSR. Series biol. and chem. sciences, 5, 58-60 [in Russian].

11 Sravnitelnaia anatomiia semian [Comparative seed anatomy]. (1988). (Vol. 2). Leningrad: Nauka [in Russian].

12 Belyaeva, T.N. (2000). Morfolohiia semian vidov Paeonia L. [Seed Morphology of Paeonia L. Species]. Sistematicheskie zametki po materialam herbariia im. P.N. Krylova Tomskoho hosudarstvennoho universiteta - Systematic notes by materials of P.N. Krylov herbarium of Tomsk State University, 25-27 [in Russian].

13 Reut, A.A., \& Mironova, L.N. (2011). Karpolohiia nekotorykh vidov roda Paeonia L. (Paeoniaceae), introdutsirovannykh v Bashkirskom Predurale [Carpology of some species of the genus Paeonia L. (Paeoniaceae) introduced in the Bashkir Urals]. Proceedings from Carpology and reproductive biology of higher plants: Vserossiiskaia nauchnaia konferentsiia s mezhdunarodnym 
uchastiem, posviashchennaia pamiati professora A.P. Melikiana - All-Russian Sci. Conf., dedicated to memory of professor A.P. Melikyan. (p. 310-312). Moscow [in Russian].

14 Zhang, K., Yao, L., Zhang, Y., Baskin, J. M., Baskin, C. C., Xiong, Z., \& Tao, J. (2018). A review of the seed biology of Paeonia species (Paeoniaceae), with particular reference to dormancy and germination. Planta, 249 (2), 291-303. https:// doi.org/10.1007/s00425-018-3017-4

15 Krasnaia kniha Kazakhstana. T. 2: Rasteniia [Red Book of Kazakhstan. Vol. 2: Plants]. (2014). Astana [in Russian].

16 Krasnaia kniha Yamalo-Nenetskoho avtonomnoho okruha: zhivotnye, rasteniia, hriby [Red Book of the Yamal-Nenets Autonomous Area: Animals, Plants, Mushrooms] (1997). Ekaterinburg: Ural Univ. Publ. [in Russian].

17 Krasnaia kniha Kurhanskoi oblasti [Red Book of Kurgan Region]. (2002). Kurgan: Zaurale [in Russian].

18 Krasnaia kniha Khanty-Mansiiskoho avtonomnoho okruha: zhivotnye, rasteniia, hriby [Red Book of the Khanty-Mansiysk Autonomous Area: Animals, Plants, Mushrooms]. (2003). Ekaterinburg: Pakrus [in Russian].

19 Krasnaia kniha Tiumenskoi oblasti [The Red Book of the Tyumen Region]. (2004). Ekaterinburg: Ural Univ. Publ. [in Russian].

20 Krasnaia kniha Omskoi oblasti [Red Book of Omsk Region]. (2005). Omsk: OmGPU Publ. [in Russian].

21 Krasnaia kniha Respubliki Bashkortostan: redkie i ischezaiushchie vidy vysshikh sosudistykh rastenii [The Red Book of the Republic of Bashkortostan: Rare and Endangered Species of Higher Vascular Plants]. (2001). (Vol. 1). Ufa: Kitap [in Russian].

22 Krasnaia kniha Respubliki Komi [Red Book of the Komi Republic]. (2009). Syktyvkar: Komi NC UrO RAN [in Russian].

23 Flora Sibiri [Siberian flora]. (1993). (Vol. 6). Novosibirsk: Nauka [in Russian].

24 Muldashev, A.A. (2003). Floristicheskie nahodki v Bashkortostane (Rossiia) [Floristic finds in Bashkortostan (Russia)]. Botanicheskii zhurnal - Botanical Journal, 88 (1), 120-129 [in Russian].

25 Krasnaia kniha Respubliki Uzbekistan: redkie i ischezaiushchie vidy rastenii i zhivotnykh. T. 1: Rasteniia $i$ hriby [The Red Book of the Republic of Uzbekistan: Rare and Endangered Species of Plants and Animals. Vol. 1: Plants and Fungi]. (2009). Tashkent: Chinor ENK [in Russian].

26 Krasnaia kniha Altaiskoho kraia. Redkie i nahodiashchiesia pod uhrozoi ischeznoveniia vidy rastenii [Red Book of Altai Territory. Rare and endangered plant species]. (2006). Barnaul: JSC «Altai» [in Russian].

27 Kamelin, R.V. (1998). Materialy po istorii flory Azii (Altaiskaia hornaia strana) [Materials on the history of flora of Asia (Altai mountain country)]. Barnaul: Publ. of Altai State University [in Russian].

28 Kotuhov, Yu.A. (2005). Spisok sosudistykh rastenii Kazakhstanskoho Altaia [List of vascular plants of Kazakhstan Altai]. Botanicheskie issledovaniia Sibiri i Kazakhstana - Botanical Investigations of Siberia and Kazakhstan, 11, 11-83 [in Russian].

29 Krasnaia kniha Tadzhikistana [Red Book of Tajikistan]. Dushanbe, 2015 [in Russian].

30 Altaiskomu botanicheskomu sadu - 80 let: almanakh [Altai Botanical Garden 80 years. Almanac]. (2015). UstKamenogorsk: Media-Alians [in Russian].

31 Nikolaeva, M.G., Lyanguzova, I.V., \& Pozdova, L.M. (1990). Biolohiia semian [Seed biology]. Saint Petersburg [in Russian].

32 Artiushenko, Z.T. (1990). Atlas po opisatelnoi morfolohii vysshikh rastenii: Semia [Atlas on Descriptive Morphology of Higher Plants: Seeds]. Leningrad [in Russian].

33 Bondartsev, A.S. (1954). Shkala tsvetov [Color scale]. Moscow [in Russian].

34 Tsvetovaia shkala Anhliiskoho Korolevskoho obshchestva tsvetovodov [Color chart of the Royal Floriculture Society] (RHS ColourChart). Retrieved from traditio-ru.org http://traditio-ru.org/wiki/ (RHS_Colour_Chart) [in Russian].

35 Zaitsev, G.N. (1990). Matematika v eksperimentalnoi botanike [Mathematics in Experimental Botany]. Moscow [in Russian].

36 Czerepanov, S.K. (1995). Sosudistye rasteniia Rossii i sopredelnykh hosudarstv (v predelakh byvsheho SSSR) [Vascular plants of Russia and neighboring states (within the former USSR)]. Saint Petersburg [in Russian]. 